\title{
Application of extreme learning machine (elm) in paper insulation deterioration estimation of power transformer
}

\author{
Hasmat Malik $^{1,2^{*}}$ and Sukumar Mishra ${ }^{1}$
}

\author{
${ }^{1}$ Department of Electrical Engineering, Indian Institute of Technology (IIT), Delhi, India \\ ${ }^{2}$ Division of Instrumentation \& Control Engineering, Netaji Subhas Institute of Technology (NSIT), \\ Delhi, India \\ *Email: hasmat.malik@gmail.com
}

Power transformer is a key component in power system network. For proper and reliable operation, the health condition of power transformer should be maintained, which is affected due to deterioration of paper insulation. The healthy condition of oilimmersed transformer is decided as per the degree of deterioration of paper insulation of the winding (PIW). The dissolved gas in oil analysis (DGA) method is conventionally used to calculate the PIW deterioration status condition. This paper presented the four status conditions assessment of PIW deterioration for oil-immersed transformer using extreme learning machine (ELM). In this paper the correlation between accumulated values of carbon dioxide $\left(\mathrm{CO}_{2}\right)$ and carbon monoxide $(\mathrm{CO})$ with insulation resistance in oil-filled power transformers is studied using ELM approach. The authors have estimated the PIW deterioration condition using proposed method for 50 transformers, as a result, appropriate maintenance scenario can be planned.

The proposed algorithm for paper insulation deterioration estimation of power transformer is shown in Figure 1 and its performance is presented in Table 1.

Table 1: ELM combination method classification performance

\begin{tabular}{|c|c|c|c|c|c|}
\hline 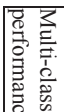 & $\begin{array}{l}\text { Mode of } \\
\text { operatio } \\
n\end{array}$ & MSE & $\begin{array}{l}\text { RMS } \\
\text { E }\end{array}$ & $\begin{array}{l}\text { Accurac } \\
\text { y (\%) }\end{array}$ & $\begin{array}{l}\text { Processin } \\
\text { g time } \\
\text { (second) }\end{array}$ \\
\hline$\frac{\pi}{3}$ & $\begin{array}{l}\text { Training } \\
\text { Phase }\end{array}$ & $\begin{array}{l}0.005 \\
8\end{array}$ & $\begin{array}{l}0.132 \\
3\end{array}$ & 99.82 & 0.0347 \\
\hline$\frac{\text { z }}{0}$ & $\begin{array}{l}\text { Testing } \\
\text { Phase }\end{array}$ & 0.009 & $\begin{array}{l}0.094 \\
8\end{array}$ & 99.10 & 0.0235 \\
\hline
\end{tabular}

References

1. Hasmat Malik, Amit Kr Yadav, Sukumar Mishra, Taekeshwar Mehto. Int J Electr Power Energy Syst., vol.
53:
pp.
256-271,
2013.

Doi.:http://dx.doi.org/10.1016/j.ijepes.2013.04.023

2. IEEE guide for the Interpretation of Gases Generated in Oil-Immersed Transformers, ANSI/IEEE std. C57.104, 1991.

3. IEC guide for the interpretation of dissolved and free gases analysis, IEC std. IEC/CEI 60599, 2007.

4. Hasmat Malik, Tarkeshwar and R.K. Jarial, Proc. IEEE Intl. Conf. on Computational Intelligence and Communication Systems, pp. 138-142, 2011.
5. Hasmat Malik, Sukumar Mishra, In Proc. 2014 Annual IEEE India Conference (INDICON), pp. 1-6, 2014.

6. Hasmat Malik, A. Azeem and RK Jarial, Application Research Based on Modern-Technology for Transformer Health Index Estimation, in: Proc. IEEE Intl. Multi-Conf. on Systems, signals and Devices (SSD), vol. 9, pp. 1-7, 2012.

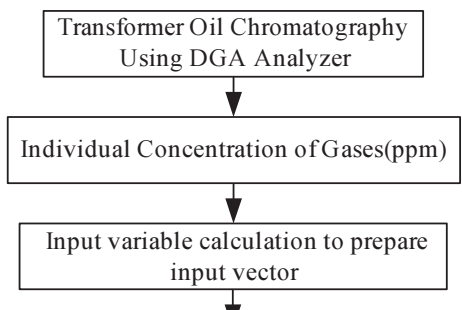

Normalized selected data [in range $(-1,1)]$ except targets

Prepare Data Format File

Set $1^{\text {st }}$ column of the data file with target value and the rest columns with different input variables

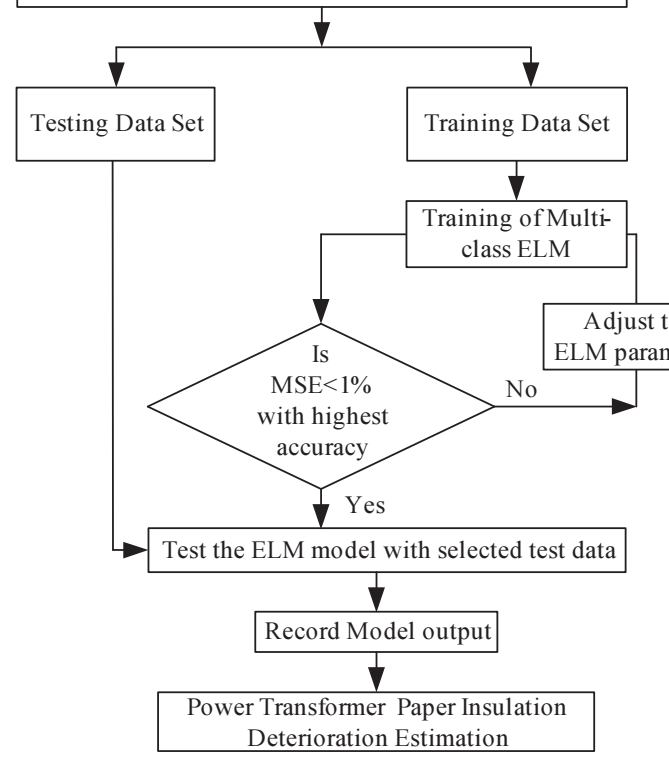

Figure 1: Proposed algorithm for power transformer paper insulation deterioration estimation 